\title{
STUDY ON THE ANTIBACTERIAL ACTIVITY OF FRUIT EXTRACTS OF KLUTUK BANANA (MUSA BALBISIANA COLLA) AGAINST SHIGELLA DYSENTERIAE ATCC 13313
}

\author{
SRI AGUNG FITRI KUSUMA*, SORAYA R MITA, INDAH FIRDAYANI, RESMI MUSTARICHIE \\ Department of Pharmaceutical Biology, Faculty of Pharmacy, Padjadjaran University, Sumedang, West Java, Indonesia. \\ Email: s.a.f.kusuma@unpad.ac.id
}

Received: 18 March 2017, Revised and Accepted: 13 April 2017

\section{ABSTRACT}

Objective: The purpose of this study is to determine the antibacterial activity of Klutuk Banana (Musa balbisiana colla) fruit extracts against Shigella dysenteriae ATCC 13313 and the amount of potassium to the discovery of anti-dysentery drug candidates.

Methods: The simplisia of Klutuk banana fruit was extracted with ethanol using a maceration method. The phytochemical screening of ethanol extract was performed using standard procedures. Determination thin layer chromatography (TLC) profile of the extract was performed using a thin layer plate. The antibacterial activity was investigated using agar well diffusion technique. The minimum inhibitory concentrations (MIC) were determined by a serial microdilution method, whereas the minimum bactericidal concentration (MBC) was done by subculturing the MIC result onto agar medium. Potassium levels of the extract were carried out quantitatively using atomic absorption spectrophotometry.

Results: The phytochemical analysis revealed the presence of flavonoids, polyphenols, tannins, monoterpenoid and sesquiterpenoids, quinones, and saponins. The TLC results prove the existence of flavonoids in the tested extract. The content of secondary metabolites that can act as an antibacterial, strengthen the antibacterial activity of ethanol extract of Klutuk banana against $S$. dysenteriae 13313 with MBC values in the range of 5-10\%w/v. Potassium levels in the ethanol extract of Klutuk banana fruits contain potassium as much as $2.919 \%$ (29 $190 \mathrm{ppm}$ ).

Conclusion: It can be concluded that the ethanol extract of Klutuk banana fruits is more potent as antibacterial against $S$. dysenteriae than as potassium supplier in hypokalemia therapy.

Keywords: Klutuk, Bananas, Shigella dysenteriae 13313, Antibacterial, Potassium.

(c) 2017 The Authors. Published by Innovare Academic Sciences Pvt Ltd. This is an open access article under the CC BY license (http://creativecommons. org/licenses/by/4. 0/) DOI: http://dx.doi.org/10.22159/ajpcr.2017.v10i7.18561

\section{INTRODUCTION}

In Indonesia, cases of diarrhea affecting mortality, 29\% caused by bacillary dysentery and generally occur at age 1-4 years [1]. Bacillary dysentery can be caused by the bacterium as follows: Shigella dysenteriae, Shigella sonnei, and Shigella flexneri [2]. However, $S$. dysenteriae is the main cause of bacillary dysentery which resulted in many deaths [3]. Patients can experience severe diarrhea, dysentery up to 20-30 times a day resulting in dehydration [4]. It had been reported that $3 \%$ of patients experienced severe dehydration from acute diarrhea hypokalemia 15\% [5], in which potassium ions in the blood of $<3.5 \mathrm{mEq} / \mathrm{L}[6]$. Manifestations of severe hypokalemia produce arrhythmias, neuromuscular excitability (hyporeflexia or paralysis, decreased peristalsis or ileus) and rhabdomyolysis [7].

According to WHO, treatment using trimethoprim-sulfamethoxazole is the main option, but $S$. dysentery has been found to be resistant against those antibiotics [8]. In addition, the resistance of $S$. dysenteriae to ampicillin, chloramphenicol, and tetracycline has occurred [9] in various countries, namely, Asia, Africa, Central America, and Europe [8]. The occurrence of resistance increases the risk of shigellosis epidemic, not least in Indonesia [10].

Considering resistant cases and essential functions of potassium in the body, it is necessary to search the natural antidysentriae which can also supply potassium hypokalemia deterrent. Other research showed that ethanol extract of Klutuk banana (Musa balbisiana) contains tannins and flavonoids [11]. Flavonoids can form complexes and inhibit the synthesis of extracellular proteins and bacterial cell wall [12]. Tannins have antibacterial activity by damaging components of cell membranes, cell walls, enzymes, genetic material, as well as other protein components [13]. It can inhibit bacterial replication process and impact on bacterial cell death.

Bananas are also reported as a source of high potassium. The average medium-sized bananas donated $440 \mathrm{mg}$ of potassium. It can overcome the effects of potassium loss due to dehydration. It is very interesting to study, especially in Indonesia; there are more than 230 types of bananas [14]. Evidence of the bananas efficacy as a source of potassium antidysentriae bacillary and preventive oral hypokalemia can increase the value and economic benefits of bananas that are very abundant in Indonesia.

\section{MATERIALS AND METHODS}

\section{Materials}

The sample that was utilized in this study is the Klutuk banana fruit (M. balbisiana), obtained from the Experimental Field Monaco, Lembang. Bananas that were used in this research have some criteria, such as 3 months old fruits, white meat, have high levels of resilience and rough taste. The bacteria that were used are $S$. dysenteriae ATCC 13313. The culture media that were used are Mueller-Hinton agar, Mueller-Hinton broth (MHB), and Shigella Salmonella agar (SSA). The chemicals used are distilled water, water fuchsine, alcohol 70\%, alcohol 96\%, amyl alcohol, ammonia, disinfectant, dimethylsulfoxide, chloroform, acetic acid solution, physiological $\mathrm{NaCl}$ solution $0.9 \%$, barium chloride solution, sulfuric acid solution, Lugol's solution, n-butanol (Bratachem), ferric chloride reagent, Dragendorf reagents, Liebermann - burchard reagent Mayer, carbon dye gentian violet, technical toluene, and Vaseline.

\section{Samples preparation}

Klutuk bananas fruit samples were identified in Plant Taxonomy Laboratory of Biology Major, Faculty of Mathematics and Natural 
Science Padjadjaran University. The simplicia of Klutuk banana fruits were extracted using a maceration method using ethanol $70 \%$ as the solvent for 72 hrs successively with intermittent shaking every 2 hrs. Then, the extracts were evaporated using a rotary evaporator at $50^{\circ} \mathrm{C}$, then continued to evaporate on a water bath until dried extract with constant weight was obtained. The extract was stored in a refrigerator at $4^{\circ} \mathrm{C}$ until time of use. The percentage yields $(\mathrm{w} / \mathrm{w})$ of the extracts were calculated using the formula below [15]:

\section{(Weight of extract $\div$ Weight of starting plant material) $\times 100 \%$}

\section{Examination of extract quality}

The examination of extract quality was done, including phytochemical screening and thin-layer chromatography assay. Phytochemical screening was done using Farnsworth method to determine the containment of alkaloids, flavonoids, tannins, Quinones, phenolics, saponins, steroids, triterpenoids, monoterpenoids, and sesquiterpenoids in the ethanol extract of banana fruits [16]

Thin layer chromatography (TLC) assay was conducted using silica gel GF 254 as the stationary phase and the upper layer of chloroform, acetone, formic acid (4:1:5) that had been saturated for $24 \mathrm{hrs}$ as the moving phase. The extract was spotted on silica gel, then prepared in the solvent. The compound then was analyzed under ultraviolet (UV) light 254 and $366 \mathrm{~nm}$

\section{Confirmation of testing bacteria}

Confirmation of the tested bacteria was done including morphological observation of the colony morphology, cell shape, and biochemical assay. Observation of colony morphology was achieved by culturing the bacteria into SSA. Observation of cell shape was done with Gram staining method [17]. The biochemical assay was done including motility, carbohydrate fermentation, indole, methyl red, Voges-Proskauer, and Simmon citrate [18].

\section{Antibacterial activity}

The antibacterial activity test was done using the agar diffusion method with the perforation method. The extracts obtained from the fruits were used for studying their antibacterial activity. A loop full of tests bacteria was inoculated with $10 \mathrm{ml}$ of sterile normal saline $(0.9 \%)$ under aseptic conditions from the stock culture maintained at $4^{\circ} \mathrm{C}$. The density of each microbial suspension was adjusted to equal that of $10^{8} \mathrm{cfu} / \mathrm{ml}$ (standardized by $0.5 \mathrm{McF}$ arland standard). The volume of $20 \mathrm{ml}$ MMA was poured into a sterilized petri dish, then $20 \mu \mathrm{L}$ bacterial suspensions with 0.5 McFarland in turbidity were added. The mixture of bacterial suspension and agar was homogenized until it became solid. Care was taken to ensure proper homogenization. The media is then perforated to make holes for storing the extract. The extract was solved on dimethyl sulfoxide (DMSO) with the comparison $1 \mathrm{~g}$ of extract was solved in $1 \mathrm{ml}$ of DMSO $(100 \% \mathrm{w} / \mathrm{v})$. Then, the extract solution was done with the variation of concentration 20,30 , and $40 \% \mathrm{w} / \mathrm{v}$ using DMSO. Volume of $100 \mu \mathrm{L}$ of every extract concentration was populated and poured into the hole. The media then was incubated for $20 \mathrm{hrs}$ at temperature $37^{\circ} \mathrm{C}$. The extract was tested in triplicates. After that, we observed the diameter of the zone of inhibition around the holes.

\section{Statistical analysis}

Antibacterial activity test data statistically processed using SPSS software using analysis of variance (ANOVA) one-way and Tukey's test with $\alpha=0.05$. One-way ANOVA test aims to determine whether or not the influence of the concentration of the extract on inhibition zone formed [19], with the hypothesis below:

$\mathrm{H}_{0}=$ There is no effect on treatment

$\mathrm{H}_{1}=$ At least there is one treatment that

Affected the bacterial growth.
Minimum inhibitory concentrations (MIC) and minimum bactericidal concentration (MBC) determination

Determination of MIC of Klutuk banana fruits ethanol extract was done using microdilution method. MIC of the extract against $S$. dysenteriae was measured using a dilution technique. The ethanol extracts of banana fruits were solubilized in DMSO and then serially two-fold diluted MHB medium to obtain a concentration range of 0,078125-20\%w/v. The bacterial strains were suspended in sterile normal saline $(0.9 \%)$ under aseptic conditions, homogenized and adjusted to an optical density of 0.05 at 530 (equivalent to $1 \times 10^{6} \mathrm{CFU} / \mathrm{ml}$ ) [20]. Volume of $10 \mu \mathrm{L}$ standardized cell bacterial suspensions was put into each tested concentration. The tested media, then were incubated for 20 hrs with temperature at $37^{\circ} \mathrm{C}$. MIC was determined from the minimal concentration of the extract which did not show any turbidity in the medium, whereas the MBC was determined from the MIC range of the extract which completely inhibited the visible growth of bacteria on solid media using the spread plate method. The tested media in Petri dishes were incubated at $37^{\circ} \mathrm{C}$ for $24 \mathrm{hrs}$. The colony growth on solid media was observed macroscopically. The highest dilution that yielded no bacterial colony on a solid medium was taken as MBC.

\section{Potassium levels in extract}

Quantitative measurement of potassium concentration was conducted to determine the content of potassium contained in the extract. Preparation of extracts made with dried destructive method and test extracts was analyzed using atomic absorption spectrophotometry (AAS). Extract weighed as much as $\pm 5 \mathrm{~g}$. Later in the furnace reaches a temperature of $600^{\circ} \mathrm{C}$ to form ash. Ashes of the test extract were then added $10 \mathrm{ml} \mathrm{HNO}{ }_{3} 6.5 \%$ and heated on a hot plate. After it is filtered into a $25 \mathrm{ml}$ flask, the solution was then added to demineralize water to mark boundaries and obtained a sample that is ready to measure.

The making of standard solution and calibration curves are as follows:

- Preparation of standard solution of potassium $(1,000 \mathrm{mg} / \mathrm{ml})$ A total of $1 \mathrm{~g}$ of solid $\mathrm{KCl}$ weighed and dried at a temperature of $100^{\circ} \mathrm{C}$ for $2 \mathrm{hrs}$ and then cooled for 30 minutes. Then, weighed as much as $25 \mathrm{mg}$ of $\mathrm{KCl}$ and put in a $25 \mathrm{ml}$ flask. Furthermore, added with demineralized water up to $25 \mathrm{~mL}$, shaken, and homogenized to obtain a stock solution of $1000 \mathrm{ppm}$.

- Determining the calibration curve

The absorbance of each standard solution was measured using atomic absorption spectroscopy using demineralize water as blank standard. Measurements were made of a standard solution with a concentration of the smallest to the largest concentration. Every measurement result recorded so obtained by linear regression and obtained the equation: $y=a x+b$ to see linearity, calculated the value of $r$.

\section{RESULTS AND DISCUSSION}

\section{Yield of the extract}

Organoleptic ethanol extracts of Klutuk banana fruits were dense, sticky, distinctive smell, and dark brown. From the rendemen calculation, the extraction of Klutuk banana yields of $11.31 \%$. Value yield is related to the amount of secondary metabolites that successfully attracted when the extraction process by comparing the weight of the extract thick with heavy bulbs. The results of the determination of water content of ethanol extract of Klutuk banana are $0 \%$. The water content in the extract should not exceed $10 \%$ to prevent mold growth in the extract [21]. Based on these data, it can be concluded that the ethanol extract of Klutuk banana used in this study has been complied with.

\section{Phytochemical screening results}

Based on the results of phytochemical screening, it is known that the chemical components of the ethanol extract of banana contain flavonoids, polyphenols, tannins, monoterpenoid and sesquiterpenoids, Quinones, and saponins. The result of phytochemical screening can be seen in Table 1. These tests reveal the presence of various bioactive secondary metabolites which might be responsible for their medicinal 
attributes, such as antibacterial [22]. This is evidenced in another study which revealed that ethanol extracts of Xylopia aethiopica fruits showed active antibacterial against $S$. dysenteriae. This was supported by the data of preliminary screening of phytochemical constituents of the presence of flavonoids, tannins, phenol, anthraquinones, saponin and steroids [23]. The chemical constituents that act as antibacterial of both the fruit extracts tend to be similar.

\section{Result of TLC}

Qualitative phytochemical screening is an essential step toward the discovery of new drugs as it provides the information regarding the presence of a particular secondary metabolite in the plant extract of clinical significance. The presence of any significant natural bioactive product indicates the necessity of separation of the compounds through suitable chromatography techniques [24]. In this study, an ethanol extract of Klutuk banana fruits showed two spots that were observed at $366 \mathrm{~nm}$ UV light yellow without $\mathrm{NH}_{3}$ reagent. Once sprayed reagent $\mathrm{NH}_{3}$ does not change color patches. This shows that the flavonoids contained belonged to flavonols [25]. The determination results of the TLC profile of the ethanol extract of Klutuk banana can be seen in Table 2 .

\section{Bacterial confirmation test}

Confirmation test was done to assure the genus and species of bacteria that were used in this study. Initial confirmation of $S$. dysenteriae ATCC 13313 is to grow in selective media Salmonella-Shigella Agar. $S$. dysenteriae grows on selective media with clear colony morphology without black core and a spherical convex [26]. Observations S. dysenteriae can be seen in Fig. 1 .

In addition to observing the form of colonies, confirmation of the bacteria has also been conducted using cell morphological observation and a series of biochemical tests. A cell morphological observation was made by Gram staining. Based on the microscopically observations, the tested bacteria was Gram-negative bacteria with a rod-shaped. Gramnegative bacteria have cell walls that are thinner and thicker lipid structures. Lipids in Gram-negative bacteria will dissolve in alcohol so as to improve seeped. These causes Gram-negative bacteria are blue when observed under a microscope as the primary staining substances (CGV-l Ugol) will be lost by flushing the alcohol so that the cells will be stained by the dye methylene blue counter [27]. Biochemical test is performed to determine the interaction of metabolites produced by certain chemical substances and to see the ability of bacteria using certain compounds as a source of carbon and energy source [28]. Biochemical tests resulted in the same characteristics as references. The results were as follows: Non motile can only ferment glucose and gave a positive result on methyl red assay. Based on the series of tests

Table 1: Phytochemical screening

\begin{tabular}{ll}
\hline Compounds & Results \\
\hline Alkaloids & - \\
Flavonoids & + \\
Tannins & + \\
Polyphenolics & + \\
Monoterpenoids and sesquiterpenoids & + \\
Steroids & - \\
Triterpenoids & - \\
Quinones & + \\
Saponins & + \\
\hline
\end{tabular}

(+): Presence, (-): Absence

Table 2: TLC assay results

\begin{tabular}{lllll}
\hline Spot number & Rf & Visible light & \multicolumn{2}{c}{ UV light (nm) } \\
\cline { 3 - 5 } & & & $\mathbf{2 5 4}$ & $\mathbf{3 6 6}$ \\
\hline 1 & 0.25 & - & - & Light yellow \\
2 & 0.58 & - & - & Light yellow \\
\hline
\end{tabular}

TLC: Thin layer chromatography, UV: Ultraviolet that we had done, we conclude that the bacteria that we were going to use was $S$. dysentery.

\section{Antibacterial activity test results}

The antibacterial activity test was performed using the agar diffusion method with perforation techniques and pour plate method. The bacteria test used is $S$. dysenteriae ATCC 13313 . The test was done with 20,30 and $40 \% \mathrm{w} / \mathrm{v}$ extract concentration in DMSO solvent. The result of the antibacterial activity test can be seen in Table 3 .

Based on the diameter of inhibition zones, all tested concentrations of the extract were categorized as a very active antibacterial (above $11 \mathrm{~mm}$ ) [29]. The antibacterial activity of the ethanol extracts of Klutuk banana fruits against $S$. Dysentery because of the antibacterial content of secondary metabolites, especially flavonoids. The same result also reported on another study that the bark extract of Terminalia arjuna showed potential antimicrobial activities against all of the selected strains of microorganisms and the greatest activity were observed against $S$. dysenteriae [30].

\section{Statistical analysis result}

The statistical analysis result is a value of 0 or significant $=\alpha<0.05$. Based on the statistical analysis result, we rejected $\mathrm{H}_{0}$ and accepted $\mathrm{H}_{1}$ Therefore, we concluded that at least there is a treatment that affected the bacterial growth.

\section{The result of MIC and MBC determination}

The lowest concentration of the tested extracts, requisite for inhibiting the growth of $S$. dysenteriae was considered as the MIC. The MIC value determined by broth dilution methods indicated that significant antibacterial activity of the ethanol extracts of $5-10 \% \mathrm{w} / \mathrm{v}$ against the tested bacterial was presented in Table 4

It was found that the data obtained from the extracts of Banana Klutuk fruit extracts required relatively lesser quantity for inhibiting the growth of testing microorganisms.

\section{Potassium quantitative test results}

Quantitative analysis of potassium was conducted using atomic absorption spectrophotometer (AAS). Sample preparation in the form of ethanol extract of Klutuk banana fruit done with the dry destruction method. Dry destruction is a method of ashing the drying process, this method can be used for almost all metals analysis. Condensed extract as much as $0.5 \mathrm{~g}$ was dried destructive and then dissolved in $25 \mathrm{ml}$ of the sample solution. Made standard solution with a concentration

Table 3: The result of antibacterial activity

\begin{tabular}{ll}
\hline Concentration (\%) & Diameter of inhibitory zone (mm) \\
\hline 40 & $14.03 \pm 0.10$ \\
30 & $13.56 \pm 0.10$ \\
20 & $12.03 \pm 0.15$ \\
\hline Perforator diameter: $9 \mathrm{~mm}$ &
\end{tabular}

Table 4: MIC and MBC Result

\begin{tabular}{ll}
\hline Extract concentration $(\% \mathbf{w} / \mathbf{v})$ & Colony growth \\
\hline 0.078125 & + \\
0.15625 & + \\
0.3125 & + \\
0.625 & + \\
1.25 & + \\
2.5 & + \\
5 & + \\
10 & - \\
\hline
\end{tabular}

$(+)$ : There is colony growth, $(-)$ : There is no colony growth, MIC: Minimum inhibitory concentration, MBC: Minimum bactericidal concentration 


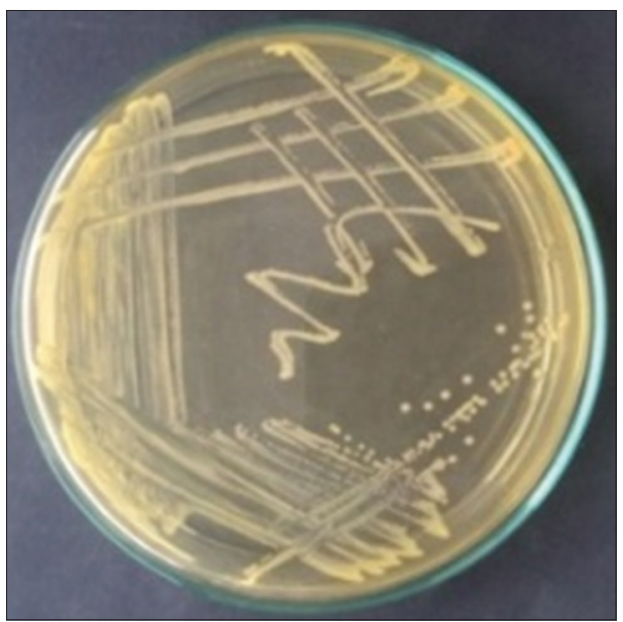

Fig. 1: Shigella dysenteriae colony

of $100,200,300,400$, and $500 \mathrm{ppm}$ is then measured its absorbance thus obtained line equation $y=0,00097 x+0.00552$. Then, a solution of test extracts was measured. From these test results, data showed that in every gram of ethanol extract Klutuk bananas contain potassium as much as $2.919 \%$ (29 190 p.m.). Based on the literature, potassium levels are required to provide potassium intake in patients with hypokalemia dysentery is $30 \mathrm{mEq}$ equivalent to $1.17 \mathrm{~g} / \mathrm{l}$ or $1170 \mathrm{ppm}$ [31].

\section{CONCLUSION}

The results of this study showed the ethanol extract of Klutuk banana fruits (M. balbisiana colla) has antibacterial activity against S. dysenteriae ATCC 13313. The range of MIC was between $5 \%$ and $10 \% \mathrm{w} / \mathrm{v}$. Using AAS, showed that the ethanol extract of banana Klutuk requires higher concentrations be able to supply calcium for the treatment of hypokalemia due to dysentery.

\section{REFERENCES}

1. Ciesla WP, Guerrant RL. Infectious Diarrhea: Current Diagnosis and Treatment in Infectious Disease. New York: Lange Medical Books; 2003.

2. Dzen SM, Santoso S, Roekistiningsih, Winarsih S. Bakteriologi Medik. Malang: Bayumedia Publishing; 2003.

3. Gerald T. Diseases caused by Gram-negative enteric bacilli in Harrison. Principal of Internal Medicine. $15^{\text {th }}$ ed. USA: McGraw Hill Company Inc.; 1996.

4. Prihantoro T, Indra R, Sumarno. Efek Antibakteri Ekstrak Kulit Buah Delima (Punica granatum) Terhadap Shigella dysentriae Secara in vitro. Malang: Universitas Brawijaya; 2006.

5. Mahalini DS, Aryasa IK, Suraatmaja S. Gangguan Elektrolit dan Keseimbangan Asam Basa Pada Diare Akut Dehidrasi Berat. Bali: Universitas Udayana; 2004

6. Hasyati S. Pengaruh Minuman Isotonik, Minuman Beroksigen, dan Minuman yang Mengandung Vitamin C Terhadap Kebugaran Fisik Setelah Latihan Fisik Dengan Metode Harvard Step Test Pada Mahasiswa Fakultas Kedokteran Universitas Sumatera Utara. Disertasi. Universitas Sumatera Utara: Fakultas Kedokteran; 2014.

7. Juffrie M. Disruption of fluid and electrolyte balance in gastrointestinal diseases. Sari Pediatri 2004;6 Suppl 1:52-9.

8. Lima AA, Lima NL, Pinho MC, Barros EA Jr, Teixeira MJ, Martins MC, et al. High frequency of strains multiply resistant to ampicillin, trimethoprim-sulfamethoxazole, streptomycin, chloramphenicol, and tetracycline isolated from patients with shigellosis in northeastern Brazil during the period 1988 to 1993. Antimicrob Agents Chemother 1995;39:256-9.

9. Kariuki S, Hart CA. Global aspects of antimicrobial resistant enteric bacteria. Curr Opin Infect Dis 2001;14 Supp1 5:579-86.

10. Levinson W, Jawetz E. Medical Microbiology and Immunolog. $4^{\text {th }}$ ed. Stanford: Appleton and Lange; 1996.

11. Ponnambalam H, Manimaran S. ICP-MS Technique For Quantification of Potassium andSodium in Spray-Dried Extract of Shoot Juice of Banana Plant (Musa balbisiana) Responsible for Anti Urolithiatic and Antidiuretic Activity. Malaysia: Taylor's University; 2014.

12. Cushnie TP, Andrew JL. Antimicrobial activity of flavonoids. Int J Antimicrob Agents 2005:26:343-56.

13. Sabir A. Antibacterial activity of flavonoid from propolis trigona sp against Streptococcus mutans bacteria (in vitro). Dent J 2005;38 Suppl 3:135-41.

14. Astawan M, Kasih AL. Khasiat Warna Warni Makanan. Jakarta: PT Gramedia Pustaka Utama; 2008. p. 115.

15. Onoja SO, Gideon KM, Maxwell IE, Chidiebere C. Investigation of the laxative activity of Operculina turpethum extract in mice. Int J Pathol Clin Res 2015;7 Suppl 4:275-9.

16. Fansworth NR. Biology and phytochemical screening of plants. IJ Pharm Sci 1966;55 Suppl 3:263-4

17. Public Health England. UK Standards for Microbiology Investigations: Gram Procedures. Available from: https://www.gov.uk/government/ uploads/system/uploads/attachment data/file/344141/TP 39i1.2.pdf. [Last accessed on 2014 Dec 30]

18. Holt JG, Krieg NR, Sneathm PH, Staley JT, Williams ST. Bergey's Manual of Determinative Bacteriology. $9^{\text {th }}$ ed. Baltimore: Williams and Williams Publishers; 1994.

19. Wahyono T. Metode Analisis Dengan Menggunakan SPSS 17. Jakarta: Gramedia; 2009.

20. Anupma D, Hemlata S, Sharma RA, Archana SB. Estimation of antioxidant and antibacterial activity of crude extracts of Thevetia peruviana (PERS.) K. schum. Int J Pharm Pharm Sci 2015;7 Suppl 2:55-9.

21. Soediro IS. Standarisasi Mutu Simplisia dan Ekstrak Bahan Obat Tradisional. Presidium Temu Ilmiah Nasional Bidang Farmasi; 1997.

22. Manjulika Y, Sanjukta C, Sharad KG, Geeta W. Preliminary phytochemical screening of six medicinal plants used in traditional medicine. Int J Pharm Pharm Sci 2014;6 Suppl 5:539-42.

23. Ilusanya OA, Odunbaku OA, Adesetan TO, Amosun OT. Antimicrobial activity of fruit extracts of Xylopia aethiopica and its combination with antibiotics against clinical bacterial pathogens. J Biol Agric Healthc 2012;2 Suppl 9:1-9.

24. Sharifa S, Adawia K, Rawaa AK. TLC screening and evaluation of antioxidant, antibacterial activity of Onopordon macrocephalum by bioautography method. IJPS 2016;12(2):1-8.

25. Markham KR. Cara mengidentifikasi flavonoida. Terjemahan Kosasih Padmawinata. Bandung: ITB; 1988.

26. Kelly FC. Microbiology. New York: Appleton-Century-Crofts Inc.; 1995.

27. Brown A. Microbiological Application Lab Manual. $8^{\text {th }}$ ed. New York: The McGraw-Hill Companies; 2008.

28. Waluyo L. Mikrobiologi Umum. Malang: Universitas Muhamadiyah Malang; 2004

29. Nurliana, Sudarwanto M, Sudirman LI, Sanjaya AW. The Prospect of Acehnese Traditional Foods as a Healthy Food: The Initial Detection of Antimicrobial Activity of Plieku Oil and Plieku Crude Extracts. Dissertation, Veterinary Science Study Program. Bogor Agricultural Institute; 2009

30. Alam MM, Azim U, Akhlaqur R, Tahrim H, Sahrov R, Abdullah A, et al. In vitro antimicrobial and cytotoxicity screening of Terminalia arjuna ethanol extract. Int J Biosci 2011;1 Suppl 2: 31-8.

31. Jawetz E. Medical Microbiology and Immunology. $4^{\text {th }}$ ed. Stanford: Appleton and Lange; 1996 